\title{
Sociology of Social Consensus and Ethnic Minorities in Iran
}

Seyed Javad Hoseini

PH.D in Sociology, Teachers University and Islamic Azad University Hoviat76@gmail.com

Maryam Sadat Tayarani

Ferdowsi University of Mashhad mtayarani@yahoo.com

Saeid Saleh

Islamic Azad University, Quchan Branch s.saleh90@gmail.com

\section{Mohammad Esmaeil Sheykhani}

Imam Reza International University ms.sheikhani2012@gmail.com

\section{Doi:10.5901/ajis.2014.v3n1p29}

\section{Abstract}

This study sets out to investigate the relationship between social consensus and ethnic minorities in Iranian society. By using library research and documentary method, the data were collected and were analyzed based on a synthetic-analytic model. This model was devised by a theoretical framework based on Causative structuralism and ethnic mobilization. The social consensus and ethnic minorities' affairs were studied on 3 dimensions. The result showed that related to social consensus and divergence, in Iranian society, Holy Qur'an instructions, Constitution law, participation, security, traditions, charismatic authority and law are basic factors. The existence of Political governors and revolutionists from different ethnic groups, the kind of relationships of center-margins, the territorial and boundaries connections, the relationships of minorities with important national and historical events and internality of ethnic groups are favorable backgrounds for social consensus. Finally, state authoritarianism, ethnic instrumentalism, Idealism, national state formation and external factors are unfavorable backgrounds for the aforementioned issue.

Keywords: Social Consensus- Ethnic minorities

\section{Introduction}

Iranian society is placed neither in the list of multination countries based on equal rights nor belongs to the multination countries based on unequal rights. It is placed somewhere between the two and at the same time has its own unique features in some aspects. People in Iran have a common historical-cultural body but this body involves some sub-cultures and cultural dialects as well.

Diversity in Iran involves all of the various aspects and all kinds of linguistic, cultural and religious dimensions and religious sects. Based on the current political geography of the world, Iran, in comparison to more than 200 countries, involves relatively the most diversity. Three major monotheistic or Ibrahimireligions(Judaism, Christianity and Islam) have their followers in Iran. Christianity has various branches and each sect has its own followers. The followers of Islam, Muslims, show much more diversity in the country in comparison to about other 50 countries that have Islam as their official and major religion (Isajiw, 1974). In most Islamic countries, almost there is only sunni branch of Islam with dominance of one of its sects. In those few countries that Shia has the most followers(Iraq, Bahrain, Azerbaijan and Lebanon), there is no such diversity as it is observed in Iran. Religion in Iran is dominated by twelverShi'ism which is the official state religion and to which about $91 \%$ of Iranians belong. Esmaeeli, another branch of Shia, also has its own few 
followers. About $8 \%$ of Iranians are sunni that mainly belong to its main sub-branches, Hanafite and Shafi'ite. The muslims aren't limited to sunni and Shia. Other muslim minorities like Yezidisand Yarsanis have added something to the diversity.

Although non-Muslims in diverse society of Iran aren't more than $1 \%$ to $2 \%$ of population, they indicate a unique religious diversity as well. They aren't limited to major religions, Judaism and Christianity, and involve Zoroastrians, Mandaens and Sikh, as well, which their place of residence is limited to Iran and one or two other countries. On the other hand, there are various ethnic groups that live in the country like Kurds, Lurs, baloches, Arabs, Taleshies, Gilakies...

Now the basic question is that how is the social consensus in a country with this ethnic, religious and linguistic plurality?

What are the fundamentaleffective factors on social consensus in Iran? What are the favorable and unfavorable groundwork of convergence and social consensus in Iran?

\section{Definitions (Ethos, Ethnicity and Social Consensus)}

The ethnic groups have complex dimensions and components. So, different scholars have studied it from different aspects. Some of them are as follows:

- Ethnic group as a cultural event (Alami)

- The status of ethnic group in a society (Park)

- The interaction and dynamics of group relationships (Oomen)

- Organization and internal solidarity (Kashmur)

- Coexistence wills(Renan)

- Kinds of tendencies and behaviors and Feelings of common experience (Cooper)

- Kinds of ideas and conceptions about oneself and others (Harrison, 1986, Entessar, 1992, Coleman, 1974)

The element of social interaction in ethnic groups is important. Usually ethnicity makes sense in the light of "others" or "out-groups". The "ethnic group" cannot be defined without taking into account the "otherness" and the relationships with those "others" (Ooman, 1997). So sociologists, specifically Kashmur consider the element of relationship with a cultural approach to definition and conceptualization of "ethnic group". In defining ethnicity, some have emphasized on ethnical backgrounds, but now, that emphasis has been given to cultural and social dimensions. Cultural and social approaches hasve been of interest to so many sociologists like Giddens (1984), Horton and Hunt (1980), Ooman (1997), Robertman (1977), Ritzer, (1995), Olson, (1918) andRatasi,(1994).

There is no consensus on the definition of ethnicity and ethnic group that can have a universal generalization, but it's not that hard to accept Smith's definition:

"The study of ethnies, named human populations with shared ancestrymyths, histories and cultures, having an association with a specific territoryand a sense of solidarity" (Smith 1986: 32).

Social consensus is closely related to concepts like social solidarity, social convergence, collective identity, even social order and group conformity, but it is considered as equal to the concept of "culture" and sometimes it is taken to mean making order or keeping balance (keshavarz and shokri, 2004, khalili, 2003). However it can be said that social consensus can be formed of 3 bases: publicized beliefs, constructional pressure and social motivation (Hoseini, 2006, khalili, 2003).

Apart from looking social consensus as something related to conceptual circle of culture or considering it in an order-oriented and balance-making approach, it has other definitions that more or less differ from both: they are as followings:

1- Common voluntary social rules based on affective affinity

2- Consensus on some common basic and normal values and ideals

3- Consensus on the ways of looking, feeling, acting and having relationships with others

4- Common preference and giving superiority to them as sacred things, in comparison to accidental and changeable priorities, to keep them safe from benefit-oriented ideas and contradicted priorities

5- "symbolic order" or "communicative society"

6- Consensus means solving contradiction by cooperating and empathy

7- Decisive decision of experts of the field about a certain problem

8- Sharing the same views among members of a group or society in an implied, covert and overt manner 
(Weiner, 1996 and Horowitz, 1985)

9- The important elements of these definitions are:

a. A kind of collective consensus

b. Aset of social rules and principles and common preferences

c. Interaction

d. Emotions

With consideration of these common elements in the definition of social consensus, Chalabi has given a nearly comprehensive definition that seems to be the most perfect one and in this research we mean it when we study social consensus:

"Social consensus is a collective consensus on a set of principles and rules that appear in a social interactive scope and simultaneously it is both the cause and the effect of social consensus (Chalabi, 1993:23).

\section{Review of Literature}

Study of scholars likeEisenshtat, Turner, Parsons, Elster, Durkheim and Weber on social consensus has attracted attention in the field. Principally, at area of social consensus there are two domains of changes and social orders that have attracted scholar's attention and two main schools, i. e. schools of "contradiction" and "functionalism" have come out of them. All of the scholars who have concentrated in social order issues have given their attention to social consensus that is both the cause and the effect of social order. On the other hand, ethnicity issues have beenat the center of attention of social science scholars. Although the studies done in this area can be considered as early steps in recognizing ethnicity discussions, two schools of archaism and Modernism have appearedabout the nature of ethnicity and ethnic nationalism. The former looks at ethnicity as an old and natural phenomenon and as a result as something universal.Shilz established it in 1950 and later it was followed by researchers like Van den Berghe, Master andWalker by adding new viewpoints. In this view, we can see a kind of relationship between ethnicity and family ties and the relationships of ethnicity- emotions among the people who imagine for themselves common ancestors or common mundane destiny (Frontiers, 1997, Herse, 2002 and Levant le, 1979).

Although archaism explains the continuity of ethnic identity in terms of time and history, it cannot answer the question that why these identities are being manifested in certain moments and why they appear in a single group, differently.

In instrumentalism, particularly in its sub-branch, situationalism, situationals believe that this fault canbe explained by considering situations and conditions.Ulzak, Gupta, Hobsbawm, Anderson, and Goldner are among those who have such a looking at ethnicity (Macromartiniello, 1995).

Although the advocates of instrumentalism have been divided to some branches based on Marxist and NeoMarxist to those theories that are related to calculating selection in the form of situationalist, instrumentalist, conditionalist and structuralist, the basic assumption is that ethnic identity is a kind of marginal loyalty to access political and economic aims in a calculating manner (Scart and Ahlers, 2002). Theoretical and experimental review of literature in the subject indicated that in Iran there are few studies about ethnic groups and if there is any, they can just be seen as some early steps. The theoretical studies in form of books and articles from 1968 up to now are given in table (1).

Table 1. Theoretical studies on Iranian ethnic groups and social consensus

\begin{tabular}{|l|l|c|}
\hline \multicolumn{1}{|c|}{ Book } & \multicolumn{1}{c|}{ Writer } & Year of publication \\
\hline Fables of Iran groups & Makan & 1969 \\
\hline Nationality and revolution in Iran & Javad Seddigh & 1973 \\
\hline Azeri intellectuals and national and ethnic identity & Ali Morshedzade & 2001 \\
\hline ethnic plurality and national identity in Iran & Ziaoddin sadr ashrafi & 1998 \\
\hline The crises of ethnic identity in Iran & Ali Altayee & 1999 \\
\hline Ethnicity in Iran: myth and reality & Hamid Ahmadi & 2004 \\
\hline Iran, identity, nationality and ethnicity & Hamid Ahmadi & 2004 \\
\hline National studies institute, quarterly Journal, No. 1 & National studies institute & 2008 \\
\hline Ethnic developments in Iran: causes and backgrounds & Mojtaba Maghsudi & 2001 \\
\hline Strategic studies, quarterly Journal, the first pilot issue & Journal of strategic studies & 1998 \\
\hline Seminar of ethnic groups and development & $\begin{array}{l}\text { The institute of teaching and researching of } \\
\text { management and planning }\end{array}$ & 1999 \\
\hline
\end{tabular}




\begin{tabular}{|l|l|c|}
\hline Between-ethnic groups familiarity in Iran & Yusefi, Ministry of the interior & 2002 \\
\hline $\begin{array}{l}\text { Sociology of social consensus and ethnic minorities in } \\
\text { Iran and the world }\end{array}$ & Seyyed Javad Hoseini & 2006 \\
\hline
\end{tabular}

Along with the theoretical studies, some fieldworks have been done on ethnic issues in Iran. There are 16 researches that are related to the present study directly or indirectly. They have been done in 4 areas:

1- Social distance and viewpoints of some ethnic groups toward national identity (6 researches)

2- Relationship among ethnic groups and their effect on Iran society (6 researches)

3- Economic- educational inequality in ethnic regions and its function in social consensus( 6 researches)

4- Effective factors on social consensus from point of views of ethnic groups (4 researches) (Hoseini, 2006)

Then we can say that there is a few theoretical and fieldwork studies on the subject. These studies have focused on some specific concepts like social consensus or ethnic affairs and they are done separately and independently. There is so few studies that bring social consensus or ethnic minorities, specifically in to scientific research. The present study has a new approach to the issue and it will offer some new data and results to the field.

\section{Theoretical Framework}

In this study, there are 3 variables: social consensus, social divergence and ethnic minorities. The main aim of the present study is to search for various effective factors on relationships between ethnic minorities and social consensus and divergence. Therefore, in conceptualization of variables and their relations we took a theoretical framework based on theoretical studies that based on it we find "causative structuralism" and some theories related to "ethnic Mobilization" appropriate for the present study.

\subsection{Causative structuralism perspective}

Based on this theory it can be said that:

1- Societies are intertwined systems that involve various social structures(political, economical, social interactions, transportation...)

2- Various kinds of stable organizing and transformation processes can be seen as the effect of the parts of the structure

Then it can be said that the level of social consensus and divergence in a society is the result of causative structure of societies. The structures can be divided to 4 dimensions: social, economical, political and cultural.Structures in mentioned dimensions can pave the way for social consensus or divergence (Chalabi, 1996 and Hoseini, 2004).

\subsection{Ethnic mobilization theories}

There are various findings about ethnic mobilization as: emphasis on social structures and economical development as main explanatory variables that were reflected in Wallerstein and Hechter's works, cultural pluralism as main variable that has been addressed in Fournivaland Smith; "competition on achieving resources" that are implied in Glaser,Moynihan, Barrett, and Olzak's works; The theory of "elite competition" that has been involved in Smith, Rothschid, especially Brass's work and finally the theory of calculating selection that has been emphasized in recent works of Hechter and Banton. In all of these theoretical schools there has been an attempt to explain the causes and methods of politicization of dependencies and ethnic mobilization in new age (Ahmadi:2004:154).

As for the ethnic mobilization, it should be mentioned that each of themexplain one part of the reality. However, they cannot explain the politicization of religious and linguistic issues in the first half of 20th century in Iran (Karimi, 2011). Relying on just one theory and its mono-casual view take us away from real understanding of the subject. To avoid it, we should rely on a theoretical framework that can analyze the ethnicityin Iran appropriayely. Therefore we will combine 3 different results of ethnic mobilization. They are: government-making models, elite competition and international system. They can give useful ideas that help explain the causes of politicization of religious and linguistic issues and their function in social consensus in Iranian society.Based on 3 models a theoretical framework will be offered. Three main variablesi.e. government, elite and international forces- have some roles in politicizing the ethnicity issue and revealing political movements between linguistic- religious groups and treating the social consensus in Iranian society (Ahmadi, 2004). As a matter of fact, with appearing of modern centralist government in Iran, the influential elites of tribes (heads of tribes and their educated descendants) resisted to political centralization and the tribe removal of modern government, and resort to 
old affairs like language and religion to call up the people(Rothschild,1981), however, the international forces supported the international movements of linguistic-religious minorities in political and cultural areas. These three variables have been main factors in politicizing the ethnic movements and their effect on social consensus in Iran.

The analytical model of ethnic mobilization

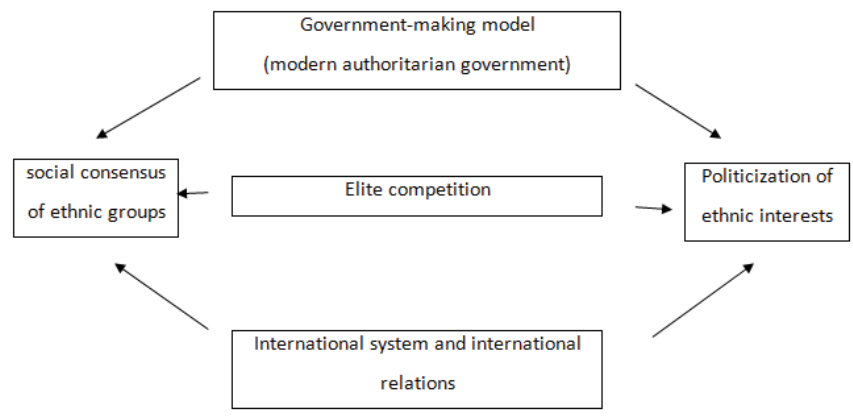

\subsection{The backgrounds and effective factors of social consensus and divergence and ethnic minorities in Iran}

The relationships of social consensus and ethnic minorities are related to 4 areas of life: political, cultural, social and economical. In this study, based on the above analytical model, social consensus and divergence issues will be addressed in political area. The other three areas will be dealt with in another study.

In political area there are many effective factors in social consensus or divergence in Iran society which will be discussed in 3 parts:

1- Basic factors that affect social consensus and ethnic minorities in Iran

2- Favorable background of social consensus and ethnic minorities in Iran

3- Unfavorable background of social consensus and ethnic minorities in Iran

A) Basic factors that have an effect on social consensus or divergence in a society are related to society beliefs, the constitution law and political fundamentals of security.

\subsection{Social consensus in Holy Qura'n}

One of the aspects of social behaviors like social consensus is the beliefs that people have in at society. Iranian society gets its most important behavioral capacity from Islam and Holy Qur'an instructions. Therefore the reflection of this Divine Book's on ideas and behaviors of people are of great importance.

From Qur'an's point of view, human factors act as cohesive ties for humans and they are rooted in deep beliefs. This looking to social consensus is different from what has been believed in nationalism, although in positive dimensions, as far as it acts as a solidarity factor, Nationalism is approved by Islam (Tabatabayee, 1984).From Islam point of view, the most important political unit is the nation of Islam, the Umma, that is indicative of a kind of public and universal consensus. The Umma can be composed of people and groups. In this view there is a kind of internationalism that satisfy the universal interests.

كان الناس /مه واحده. (baghara, Verse No. 213)

(All) people are a single nation.

In Holy Qur'an there are many verses that encourages the social consensus directly. They are: Alay Imran (verses No. 1, 103, 110, 155, 159), Naba (26), Nisa (1,35), Maidah (2), Rum (21, 30), Marium (96), Baghara $(143,213,256)$, Baraat(71, 109), Anfal (63), Shura(13,38), Maidah (68), Ghashiyah (18), Anam (59, 165), Nahl(62), Anbiya (107), Saba (28), Fath (28), Saff (9), Bani-Isael (70), ( Hujurat, 11).

\subsection{Social consensus in Iran constitution law}

In political area, the constitution of a society establishes the political system of that society and these fundamental laws can have a high potential for social consensus or divergence. For this reason, we introduce some principles of Iran 
constitution that make the ground for social consensus.

1- In individual and humanistic area, articles №. 19, 56, 154 which are based on equal rights of people

2- In individual right area, articles No. 12, 13, 14, 20-27 governs on freedom, immunity, prohibitions and limitations.

3- In symbol area, article №. 15-18, common script, language, official date and announcement the existence

4- In Legislative area, articles No. 57, 59, 65, 66, 68, 69, 73, 74, 77-83, 86-89, 92-95, 98 and 99 on selection of representatives and consultative Assembly's control on affairs of the country

5- In Judiciary area, articles No. 156, 159-162, 164, 166, 168, 171 and 172 onobservation of the accused rights and citizen rights.

The mentioned articles in constitution laws involve different components of social consensus among the ethnic groups, minorities and all the people in the community. These articles control the sanctities and honoring and attempt to provide people with what they don't have. All people in community and ethnic, linguistic and religious minorities are considered as Iranian citizens that this emphasis is a central axis for social and political consensus in Iranian society.

\subsection{Social consensus and political legitimacy basics}

In this area the question is that how cultural values affect on political system legitimacy? In other words, how the members of a political system, based on their criteria, norms and values look at the legitimacy of that system. To answer the question it can be said that if people follow a system according to the present traditions, the system has a traditional legitimacy and if they follow a system based on the divine light of the leader, then that system will have a divine legitimacy and if in a system, policy making and employing people in a legal and intellectual manner, that system will have a legitimate legal-intellectual dominance (Horowitz, 1971, Tiryakion, 1985,and Deutshe, 1961).

As a result the cultural basis of legitimacy is composed of: tradition, divinity and intellectuality. These cultural bases lead to legitimacy of a political system and social consensus. In other words, social consensus is formed by tradition, divinity and intellectuality(Bates, 1995, Hechter, 1914).

In order to know which bases the social consensus has in Iran, we can trace the discussion in each historical period: pre-Islamic, Islamic, safavid dynasty period up to Islamic revolution and after Islamic revolution.

It can be said that the social consensus in the first period, pre-Islamic period, was divinity. People obey the power authorities because they suppose they deserve it and God has gifted them the divinity light (Rajayee, 1992:7).

The social consensus in Islamic period was based on religious traditions, customs and rituals. From safavid period to Islamic revolution, the factors of social consensus were religious traditions, customs and rituals of Shia, and a belief to divinity of safavid kings (Ibid, p. 8).

The revolution was a turning point because at the beginning western thoughts and ideas made their way toward Iranand in this way the cultural social consensus was transformed. The traditions, customs and rituals were no longer bases for social consensus; instead it found intellectual-legal bases. During this period, Iran for the first time had the constitution law and legislated man-made rules, both based on social conventions and ideas. From then on, people gained access to social consensus, and social solidarity was reinforced based on the conventions.

After the Islamic revolution, bases of social consensus on traditions were empowered again and along with legal and intellectual factors (with ratification of the new constitution law in Iran after revolution)and charismatic base led to social consensus and solidarity. The charismatic base that was appeared after the revolution because of thecharismatic leadership guarantees the social consensus and integrity of regime against all of the conspiracies of the opponents.

\subsection{Participation, safety and social consensus}

The social consensus problems at the process level in Iranian society wereconcentrated on participation in political system. In Iran, at least until the constitutional period, dictatorship was dominated and just one person or one group has the right to participate in political system. In constitution government, participation of the whole people in political system became feasible through formation of the parties (AmirAhmadi, 1992). The more participation rates, the more establishment of the social consensus in Iran (Tabrizniya, 1992). Furthermore, social consensus in Iranian society, in another level, is related to security area. The central issue is that which values and affairspeople of a society prefer. These can be freedom, equality, justice and security. There are at least two reasons why Iraniansprefer security issue: 1They always have been attacked by their enemies. 2- They always have been governed by autocratic governments. Therefore, we can conclude that in Iran, in social consensus and solidarity subjects, value of security is of more 
importance than other factors. That is why immediately after the constitutionalrevolution Iranians' first demand was the establishment of a justice office.

\subsection{The favorable background of social consensus and ethnic minorities in Iran society}

\subsubsection{Political governors and revolutionists and ethnical groups}

One of the important points in relation to social consensus, ethnic groups and minorities is that to what extent the political and social system that governs the society hasethnical attitudesin delivering authority to political leaders. Iranian society has indicated that political leaders from different ethnic groups governs people in different periods and the power change hands among the ethnic groups and the society has not been sensitive to it (Maghsudi, 2001, Ahmadi, 2004 and Atabaki, 2005).

\subsubsection{Capital (center-margins) and ethnicity}

Another indicator of ethnic consensus in a society from political point of view is that how much the political sensitivity is needed on choosing the capital as a center for decision-making and political centralization, in comparison to cities with ethnic-groups residents. The history of politics in Iran has shown that capital of the countryin different periods has been in cities like Tabriz, Ghazvin, Shiraz, Mashhad, Tehran and Esfahan. Some of the cities have ethnic identities but there has been no objection to it from the side of political activists and political society.

In Iran, There had been no city that would have been a permanent center for political power during the historical periods as opposed to cities like Constantinople and Rome that were the center of empire authority for a long time. In past 400 years, Iran has had different capitals. Some of the reasons of the displacement of the capital, the political power center in Iran, have been the "background of theirestablishment, similar social and political structures and similar economic factors ( Ehlgress, 1992).

Formation of a powerful and concentrated government of safavid dynasty began at one of the west-north cities of the empire. This city, Tabriz, was the meeting point of the ethnic and cultural merging of two empires: Iran and Ottoman. Then Ghaazvin was the capital of safavid dynasty which involved a mix of Turkish and Persian-speakers. Then the capital was transferred to Esfahan that most of its population were Persian-speakers.

After the fall of safavid dynasty, in Nadershah's short governing period, Mashhad was the capital of Iran but when Karimkhan-e-zand was in power, it gives its place to Shiraz. WhenQajar dynastytook power, the capital of new government was Tehran.

The first outcome of assignment a new city as capital was a high improvement of political, social, and economical position of that city. The new situation for the city increases the population and changes the ethnic structure. For example, the population of Mashhad increased about 250,000 persons when it became the capital of the country (ibid, $p$. 156).

During the urban history in Iran, there were some ethnic conflicts among the minorities but no such religious or ethnic diversity has led to annihilation of a city. Although a change in the capital position has an effect on the position of former capital, especially on its population, it didn't lead to a basic decline of it, as some studies have claimed it. Each of these former capitals took a position as official center for the relative state and kept their economical importance and performance.

\subsubsection{Social consensus,territorial connections and political boundaries in Iran}

Until 20th century the borders of the country had a changeable state. With attempts of Safavid dynasty to access to a political unity through centralization and institutionalization of Shia, Iranian faced up with a new identity that recognizes them from the people beyond the boundaries. For the Iranian nationals of Safavid, this was not "national' characteristics that distinguishes them from others. What makes them different, was a kind of local feature, i. e. a negative one, which shows itself against their Sunni neighbors.

Along with these changesthat were effective in formation of following and loyalty to Safavid kings, drawing the first quasi-modern European maps of Iran in $17 \& 18$ centuries has an effect on establishing a territory extended from Mazanderan Sea on the North to Persian Gulf on the south. The maps in this period which were drawn based on Safavid territory were different from the past drawings of old Iran. 
In fact based on these maps Nadershah emphasized on the protection of legitimate borders of Iran and ask for giving back the north and northwest areas that Ottoman have prevailed over. This action was not confined to Nader shah. Karimkhan-e-zand and Agha-mohammad khan acted in a similar way.

During the 19th century and after two successive wars against Russia in 1813 and 1828 and a treaty with UK in 1875 , Iran lost some of the north and east states and was reduced as the present form. Then the lost east lands became a part of the newly established government of Afghanistan and the lost north parts merged in to Russia Empire.

The process of delimitation of boundaries and determination of "international boundaries" during the 19thcentury wars and their treaties led to formation a kind of territory identity among Iranians. Formation of boundaries emphasized on Iranian identity from the territory dimension not the linguistic one.This emphasis made land and geography as requirements of being Iranian. "Closed" boundaries called together a collection of people each with an ethnic background under the clear government of a king. Although on the past the nature had limited the comings and goings and the local rulers had made the ruling affairs vague, in the late 19th century, new treaties and political policies of great power authorities led to new definition of geographic power, and in some cases, to some new and artificial boundaries based on cultural affairs.

The delimitation of boundaries conjoined with some attempts for government centralization. The empire royal court accepted the principle that the survival of the center depends on the cooperation of the marginal areas. Along with the delimitation of the realm of monarchy, the tendency of Iranians to achieve nationality increased. Iran was no longer a land that belonged to a king, but it consists of a nation that was a set of beneficiary citizens. With occurrences of World Warl, since there was no powerful government, it was predicted that Iran, like Ottoman would bedivided to smaller governments. But it didn't happened and it could preserveits territorial integrity. The occurrence of Russia revolution was a favorable factor because on one hand it put an end to excessive avarice of Russia toward Iran and on the other hand it had the outcome that appearing a powerful and autonomous Iran to prevent penetrating the Communism became priority for the west. When this happened, i. e. tendency for the nationality and accepting the principle that the survival of the center depends on the cooperation and accompaniment of the marginal groups, linguistic, religious and ethnic minorities and the marginal groups, attract more attention and they increase the social consensus grounds.

\subsubsection{Important national and political events}

Another important indicator that can evaluate the relationship between ethnic minorities and society based on social consensus and divergence is the important national and political events and the role of ethnic groups. In this regard, there is 3 brilliant examples: the constitutional revolution which its leaders were of a Turkish ethnic identity and their revolution was supported by all Iranians, The Islamic revolution in which all of the ethnic groups participated and finally, the war that Iraq imposed on Iran, in which all of the people from different linguistic, ethnic and religious groups engaged (Pahlavan, 1993). While Arab ethnic groups were at the border provinces at the front line, all Iranians engaged in a broad based and all-out support to defend of the country and the liberation of the cities. The attendance of Arab, Bakhtiaries, Gilanies, in constitutional revolution was a good example of collective attempts of ethnic groups for achieving a common goal (Ahmadi, 1999).

\subsubsection{Internality of Iranian ethnic groups}

The long history of Iranian cultural identity shows that this identity has a few thousand years old. All of the Iranian ethnic groups like Kurds, Azeris, Baloches, ... are of Iranian nationality. For example Kurds were those Iranians who escape to mountains because of fear of Snake-on- shoulders Zahak, and reside there. The kings, whether those who were Iranian and speak Persian or those who don't know Persian, acted like that. In this way, all of the Iranian ethnic groups, Persianspeaking and non-Persian-speaking have participated in establishing a huge heritage that shape cultural identity of Iran (Ahmadi, 1999:220).

Therefore one of the main characteristics of this ethnic diversity in comparison to other countries that are multiethnic countries is "aboriginal" nature of various ethnic groups in Iran. In other words, being Iranian is for ethnic groups a unique feature while in othercountries which have ethnic diversity; it was an outcome of ethnic migration.

This feature can be seen in diversity of languages and dialects that are spoken everywhere in the country. Most of these languages and dialects are in the group of Iranian languages. This variety of languages and dialects in Iran, like existence of ethnic groups that are residents in this land, hasan internal dimension and is related to internal variety of the country, in spite of other countries that have some kinds of linguistic diversity, but it has an external aspect and has been 
formed by migration from outside to inside of the country. Therefore although the linguistic, religious and racial diversity of social consensus in Iran has led to some critical situation in relation to social consensus in the late half of the $20^{\text {th }}$ century, it has acted more as an effective factor in consolidation of social consensus.

A national scaling which was done in 1998, titled as "ethnic identity and its relationship to national identity" in different areas of the country indicate that as a whole the ethnic groups relations can be divided to two parts. First, relations based on cooperation. Second, relations based on conflicts (Yusefi, 2004), although ethnic cooperation and status index of ethnic groups is different. According to the results of the national research, the least cooperation with other ethnic groups belonged to Azeris and the most cooperation belongs to Bloch, while other ethnic groups have the least cooperation with Bloch.

While Persians have nearly the least cooperation with other ethnic groups, they received the most cooperation from others. It means that Persians is more receiver of the relation not the sender and they consider themselves less in need of having relations with other ethnic groups. If we look at status index of the ethnic groups we can see a hierarchy of status index of 5 ethnic groups as follows. Persians have the highest position and Bloches have the lowest. Azeris and lurs are placed in the hierarchy after Persians, respectively ( Yusefi, 2004). On the other hand, the result of the national scaling about the ethnic conflict relations showed that Kurds have the most conflict with other ethnic groups and other ethnic groups have the most conflict with Persians and Kurds respectively. On the contrary, Baloches has the least conflict with other ethnic groups and other ethnic groups have the least conflict with Baloches. However it must be mentioned that although it was shown in national scaling that Kurds of Iran have more conflict with other ethnic groups in comparison to other ethnic groups, the proximity rate between Kurds and Persians are high and they have so low centrifugal tendencies, in comparison to Iraqi and Turkish Kurds. Entessar has mentioned that Iranian Kurds are culturally more close to other Iranian ethnic groups than to Iraqi or Turkish Kurds... On the other hand, separatism tendencies among Turkish and Iraqi Kurds are more powerful because Turkish and Arab culture are more alien for Kurds than Iranian culture (Entessar, 1992).

In conclusion the research has shown that as a whole the relations based on cooperation among the ethnic groups are more than the relations based on conflicts. That is to say internality of ethnic groups indicates the social consensus and convergence capacity among them are more than the social divergence.

\subsection{Unfavorable backgrounds of social consensus and ethnic minorities in Iran}

\subsubsection{The authoritarianism, reductionism and misuse of ethnic groups}

The authoritarianism of modern government and especially the suppression and discrimination moves toward Iranian ethnic groups by Reza shah is the most important internal factor in intensification of ethnic differences. The other internal factor has been the reductionist politics of political system. Before Islamic revolution, in Pahlavi period, there has been so much emphasis on "nationality" and the government didn't pay any attention to religion. On the contrary, after the revolution, the religion has been emphasized on and "nationality" has been overlooked or fade and both of these reductionist policies has had an effect on intensifying the ethnic differences (Maghsudi, 2002, Hoseini, 2006, Hambly, 1992, Atabak, 1993 and Katm, 1371). The third internal factor of ethnic differences is related to misuse of ethnic problems in Iran society. In this regard, the role of ethnic and non-ethnic elites are outstanding. With adding fuel to ethnic problems in regions like Baluchistan, Kurdistan, Torkamansahra and Khuzistan, particularly after the Islamic revolution victory, these elites tried to benefit of local support for their plans and this led to an increase in ethnic expectancies, while not receive any answer to these expectancies by the political system and therefore the ethnic crises appear.

\subsubsection{Idealism versus national benefits}

One of the main attempts of neibouring countries for exerting pressure on Iran has been the fanning the flame of ethnic groups problems, in relation to foreign policy of idealism that appeared after the revolution (Ahmadi, 2004). While these idealist policies has continued during the first decade of revolution, up to 60 s, it was directed toward a kind of realist policy. Anyway, it should be mentioned that there is still some important manifestation of idealist foreign policy in some affairs in Islamic republic of Iran's foreign policy. Having the idealist foreign policy, particularly when it takes the form of disagreement with international norms, rules and their structures, it can have a widespread negative effect on national security. Part of these security treats can show themselves in the form of supporting ethnic moves. The support of America and England of forbidden-flight region of Kurdistan in Iraq and protection of it against each martial action of Iraq 
is a good example of these international interferences in ethnic affairs of the countries (Hoseini, 2006).

\subsubsection{Formation of a national state, social consensus and ethnic crises}

Another important point is related to formation of a national state in Iran. Some ascribed it to Safavid government. But it should be accepted that it formed, in its modern shape, through victory of constitutional revolution (Maghsudi, 2002). In the constitution law ofconstitutional government, there were problems that could produce a feeling of discrimination in long-term period in some ethnic groups like the emphasis on official religion and the possibility of access to political and official authorities in the society. This conditions in Rezakhan period that has been considered as the autocracy in Iran became worse and the ethnic problems turn to a critical situation because of the suppressive policies of him and it led to crises like Azerbaijan and Kurdistan, Gonbad, Arabs and Baloches in Khuzistan and Sistan-and-Balochistan (Atabaki, 11994, Hambly,1992, Katm, 1992 and Maghsudi, 1999). With occurrence of the Islamic revolution and some changesin political system, lack of a complete and powerful establishment of central state, because of a transfer period, led to some ethnic crises for example in Kurdistan, but with passing of the time and along with the policies of Islamic republic government the crises decreased and vanished, even though there are some Sunni and some ethnic groups like Arabs that can be potential factors that if not is dealt with by proper policies, they can be the factors that can affect on divergence in Iran society. Ethnic crises in Iranian society have passed 3 stages: before Rezashah government, from the middle of World War II to the end of the war and finally the early years of Islamic revolution victory. Before Rezakhan there were no ethnic tensions. What has been observed were only tribal tensions that didn't have ethnic identity. In Rezashah period, these tensions increased and in the early days of the revolution, because of transformed nature of political system for a kind of divergence feeling in some ethnic groups can be observed. In all of the cases, the interference of the foreign countries is so evident.

\subsubsection{Role of foreign factors in social divergence and ethnic minorities}

In Iranian society, there have been some tribal tensions that didn't have ethnic identity. In this tensions, usually the leader of a tribe has been in conflict with the central government or has some problems with other tribes but the role of external factors have been very important. Sheikh khazal is a recent example that was directed by Britain for a separation move. Then the Englishmen came to the conclusion that it was better for the government to forget Sheikh Khazal's movement. Another example was Simku (Esmaeel Agha) that united with Russia in Kurdistan, sometimes engaged with Azerbaijan and sometimes he massacre Kurds. Anyway, the important point of ethnic crises in Iran refers to the role of interference of foreigners. For clarifying the claim we will mention some ethnic crises in 4 historical stages as some example.

1- From 1920 on we can see that the ethnic interference in Iran decreases and in some cases they increased to the upmost degree. The main reason is related to the support or lack of support of an external factor. There is some problems entire the country, in Balochistan, Khuzestan and Kurdistan for example. But when Britaingovernment stops to support ethnic groups, ethnic crises subsided gradually.

2- During 1930 to 1933 there were the oil crises with Britain. In these years the ethnic tensions increased and this process continued to 1947 and the interference of foreigners and the amount of occupation the country reached to its most up and the ethnic tensions increased too.

3- In Mohammad Reza Pahlavi period of governing, there was a smooth process of ethnic tensions. Only in 1963 to 1967 with victory of Kennedy in America, there appeared some reasons for the decrease of support of America from ethnic groups and as a result the ethnic tensions decreased.

4- In 1979 which is the beginning of stability of Pahlavi government, Iraq regime first support of all ethnic groups and ethnic tensions increased. Then, the more it became weak, and its support decreased, the less ethnical tensions appeared.

\subsubsection{The boundary, social consensus and ethnic minorities}

The borders, in all countries from geographical point of view have been of great sensitivity in relation to social consensus and divergence of that society (Zarghani, 2010) . Principally, there were two issues, border and minorities, that have a high degree of sensitivity in political-social areas in relation to the problems of social consensus. Now if they are merged as what happened in Iranian society, in all borders of the country the ethnic minorities were established (Ramazanzade, 1998). The borders of Iran for this reason have some geopolitical characteristics as following: 
1- In all border points the ethnic minorities have taken up positions (Turks, Kurds, Arabs, Baloches and Turkmen)

2- In addition to being linguistic and ethnic minorities, they are considered religious minorities, too. Most of them (non-Arabs) are Sunni.

3- Furtheremore, they are neighbors of similar ethnic groups in neighboring countries. For example, Arabs are neighbors of Iraq, Baloches are neighbors of Pakistan, Turkmen are neighbors of Turkmenstan, Turks are neibors of Turkey...

It is evident that this kind of positioning that was formed in previous centuries was very vulnerable. If a proper masterstrategy isn't being executed, the backgrounds of some divergence will be a future possibility (Eftekhari, 2009). As an example, Azeri nationalism was an outcome of the developments on the sidelines of Muslim-residents of Russia Empire in Caucasus that at the end of world war I led to foundation of a country called Azerbaijan in that area. Another example is Kurds' ethnic demands that can be considered as a result of the formation of Kurd nationalism in Ottoman areas.

On the whole, the situation of 6 main ethnic groups in Iran based on population, residence area, neighbors, population distribution, religion, economic conditions, activity factor, the main axis of political stripes and the amount of activity and rupture is reflected in the following table and Map. (Table 2) (Map. 1)

Map 1: Map showing ethnic and religious diversity among the population of Iran

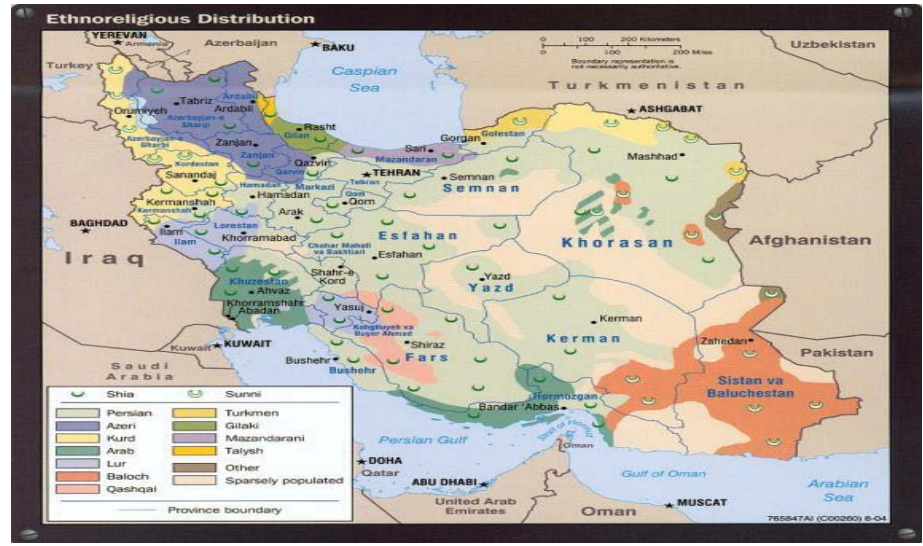

The status of various ethnic groups in Iran (Eftekhari, 2009)

\begin{tabular}{|c|c|c|c|c|c|c|c|c|c|}
\hline $\begin{array}{l}\text { Ethnic } \\
\text { group }\end{array}$ & $\begin{array}{c}\text { Population } \\
\text { (million) }\end{array}$ & Residence area & Neighbors & $\begin{array}{c}\text { Distribution } \\
\text { of } \\
\text { population }\end{array}$ & Religion & $\begin{array}{c}\text { Economical } \\
\text { status }\end{array}$ & $\begin{array}{l}\text { Activity } \\
\text { factor }\end{array}$ & $\begin{array}{c}\text { The main axis } \\
\text { of political } \\
\text { tendencies }\end{array}$ & $\begin{array}{c}\text { Amount of } \\
\text { activity/rupture }\end{array}$ \\
\hline Turk & $2-5$ & $\begin{array}{l}\text { Ardebil, East } \\
\& \text { West Azerbaijan }\end{array}$ & $\begin{array}{l}\text { Turkey, } \\
\text { Azerbaijan }\end{array}$ & Scattered & Shia & Fairly good & Language & $\begin{array}{c}\text { Autonomy, } \\
\text { independence }\end{array}$ & Low \\
\hline Kurd & $4-5$ & $\begin{array}{l}\text { Kurdistan, North } \\
\text { Khuzistan, } \\
\text { Kermanshah, } \\
\text { Hamedan, West } \\
\text { Azerbaijan }\end{array}$ & Iraq, Turkey & $\begin{array}{c}\text { Semi- } \\
\text { centralized }\end{array}$ & Sunni & $\begin{array}{c}\text { Average to } \\
\text { low }\end{array}$ & $\begin{array}{l}\text { Religion, } \\
\text { language }\end{array}$ & $\begin{array}{c}\text { Struggle for } \\
\text { independence }\end{array}$ & Average \\
\hline Arab & 1 & Khuzistan & Iraq & centralized & shia & average & $\begin{array}{c}\text { Language, } \\
\text { race }\end{array}$ & Nationalism & Low \\
\hline Lur & $3-4$ & $\begin{array}{l}\text { Lurestan, } \\
\text { Kohkiluye and } \\
\text { boirahmad, llam, } \\
\text { Chaharmahl-and- } \\
\text { bakhtiyari }\end{array}$ & Iraq & $\begin{array}{c}\text { Semi- } \\
\text { centralized }\end{array}$ & shia & low & --- & Tribal autonomy & Very Low \\
\hline Baloch & 2 & $\begin{array}{l}\text { Sistan-va- } \\
\text { baluchestan }\end{array}$ & $\begin{array}{l}\text { Pakistan, } \\
\text { Afghanistan }\end{array}$ & Centralized & Sunni & Very low & $\begin{array}{l}\text { Religion, } \\
\text { economy }\end{array}$ & $\begin{array}{c}\text { Struggle for } \\
\text { independence }\end{array}$ & Average \\
\hline Turkmen & 1 & Mazanderan & Turkmenistan & centralized & Sunni & average & $\begin{array}{l}\text { Language, } \\
\text { religion }\end{array}$ & $\begin{array}{c}\text { Struggle for } \\
\text { independence }\end{array}$ & Very Low \\
\hline
\end{tabular}




\section{Discussion and the Results}

Iran is a countrywith a fairly high religious and ethnic diversity. Countries like India, Pakistan and Afghanistan (in Asia) and Spain (in Europe) may have such an ethnic diversity. These conditions make the social consensus and divergence of a special sensitivity.

Another important point is that although ethnic groups in Iranhave achieved ethnic awareness, they are bordered with neibourings that have the same language. It is rare case in the world that a country has such status in 5 directions. We know that ethnic crises usually shows themselves in borderlinesespecially those borderpoints that ethnic groups reside in and also we know the culture of most of the people on theother side of the border is similar to minorities' culture on the border lines. This is true for Iranian society. This subject is one of the most serious problems that if it doesn't meet appropriate politic strategies by central state, it can be considered as a serious effective factor on decreasing the social consensus in Iranian society, especially since Iranian society from the religious point of view has been faced with some kind of inadequacy and intolerance because it has an official religion. Ethnic crises in Iran are mainly the result of 4 factors: foreign interference, the unequal economic conditions among ethnic groups, rights that is devoted to ethnic groups and political conditions, freedom or suppression that is executed for ethnic groups by central government and political system.During the history, along with these conditions, ethnic groups'crises have appeared and have had an effect on social consensus and divergence. But in Iranian society, these demands havea potential answer for realization in the constitution law, especially in articles 15 and 19. Anyway, there had been two approaches, reductionism and generalization that had been two obstaclesagainst true understanding of the ethnic groups in Iran.

Reducing the whole discussion to a "security" event, as it is expressed in some official expressions, and overlooking "security" dimension of it in the expressions that want to criticize the related viewpoints are some examples and are indicative of a deep distance between the attitudes of some parts of the government and attitudes of some groups of people. In Pahlavi government there was a sever emphasis on historical and national affairs and less attention was devoted to religion. People reacted to it in the form of a revolution and annihilation of Pahlavi regime, while after the revolution, in reaction to Pahlavi's policy there was an emphasis on religion and the national-historical affairs nearly received no attention. Considering the misuse of this problem, by both ethnocentrism inside the country and foreign policies, this can act as a factor in undermining the social consensus in Iran. In conclusion, there are two important points about ethnic minorities and social consensus in Iranian society: First, ethnic activities in Iran like nationalism of Kurds, Turks ... in an independent way hadn't been so active and it seems that solidarity exists among the ethnic groups. Second, now, the political tendencies of ethnic groups in Iran are affected by economic and religious considerations and outside border activities. However, with considering the political geography of ethnic groups, residence and their neighborhood, it is evident that first: all of the ethnic groups in Iran in borderline areas are placed. Second, they are interrelated and centralized. Third, they are neighbors of similar ethnic groups in neighboring countries. Obviously this way of settlement that has been formed in previous centuries and now is a natural giving for Iran security is completely vulnerable and it is possible that in the absence of an appropriate and comprehensive strategy it can pave the way for social divergence in future.

\section{References}

Altayee, A. (1999). Crisis of ethnic identity in Iran. $2^{\text {nd }}$ edition. Tehran: Shadgan.

Amir Ahmadi, H. (1992). Ethnicity and security. Translated by: Hasan Shafiee. Journal of strategic studies.

Ahmadi, H. (2001). Ethnic groups \& national security of Iran: a collection of lectures \& articles presented in public security \& national unity conference. The security vice-president office in Ministry of interior. Tehran: Security research \& studies office.

--. (2004 a). Ethnicity \& Ethnocentrism in Iran: myth \& reality. $4^{\text {th }}$ edition. Tehran, Nashreney.

(2004 b). Iran, identity, nationality \& ethnicity. Tehran, The Institute of research and developments in humanities.

(2008). Iranian ethnic groups \& Iranian identity: Iranian identity at the end of 20th century. Motaleate melli, 1.

Atabaki, T. (1993). Nationality \& autonomy in contemporary Iran, Goftegu, 3.

.- (2005). Ethnic diversity and territorial integrity in Iran: Internal compatibility \& regional dangers, Goftegu, 43 (2005).

Ayubi, H. A. (1998). The ethnic gaps \& violence in political conflicts. Journal of strategic studies. Institute of strategic studies.

Bates, R. (1914). Ethnic competition and modernization in contemporary Africa. Comparative political studies,6:457-81.

Chalabi. M. (1993). Social consensus. Social consensus letters. Vol. 2. No. 3.

. (1994). Sociology of order. The theoretical analysis \& expounding of the social order. Tehran: Nashre ney.

(1999). Ethnic identity \& its relation to national identity in Iran. Tehran: Office of social affairs in Ministry of interior.

Coleman, J. (1974). The development syndrome: Diffrention-Equality-Capacity. In: Leonard Binder and thers (eds) Grises and sequenes in political Development. Princeton University press. PP.11-18. 
Constitution Law of Iran (2005). 24th edition. Tehran: Nashre dowran.

Cottam, R. W. (1992). Nationalism in Iran. Translated by: Ahmad Tadayon. Tehran: Kavir.

Deutsche, K. W. (1961). Social mobilization and political Development. American political science revivew. Vol. 55.

Deutsch, K. W. (1999). Nationalism \& its types. Translated by: Mohamad Meghyasi. Tehran, Institute of national studies.

Eckartehlers. ( ) Capitals and spatial organization in Iran:Esfahan, shiraz \& Tehran. In: C. Adle and B. Hourcade (Ed). Tehran.

Eftekhari. A. (2000). The natural security capacity: A case study of ethnicity \& violence in Iran. Journal of strategic studies. Forefront No.2

Encyclopedia of The Shiites. Tehran: Encyclopedia of The Shiites organization. Vol. 2.

Entessar, N. (1992). Kurdish ethno nationalism. Boulder, Lynn, Rienner.

Hambly, G. (1992). Autocracy of Pahlavi: Mohammad Reza shah, Pahlavi dynasty \& religious forces in narration of the history of Cambridge. Translated by: Abas Mokhber. Tehran: Tarhe now.

Harrison, S. S. (1986). Ethnicity and the political statement in Pakistan. In Banuazizi and M. weiner (eds), The state, religion and ethnic politics: Afghanistan, Iran, Pakistan and syracyse. New York university press.

Hechter, M. (1914). The political economy of ethnic change. American Journal of Sociology, 79:1151-78.

Holy Qur'an. Translated by: M. H. Shakir. Qom: 1993.

Horowitz, D. L. (1985). Ethnic groups in conflict. Berkeley, university of California press.

Horowitz, D. L. (1971). Three dimensions of ethnic politics. World politics, 23: 232-4.

Hoseini. S. J. (2006). Sociology of social consensus \& ethnic minorities in Iran \& the world. Mashhad: Faraangizesh.

Hourcade, B. (2002). Iran, Nouvelles identitie's d'une r'epublique,ed. Bbelin:paris.

Isajiw, W. W. (1974). Definition of Ethnicity. Ethnicity. No.1.

Karimi, A. (2011). An introduction to political sociology of ethnic diversity: Problems \& theories. Tehran: Samt.

Kashani-Sabet, F. (1997). Fragile frontiers: The Diminishing Domains of Qajar Iran. Int. J. Middle East Stud, 29: 205-234.

Lowenthal, R. (1979). Political legitimacy and cultural change in west and wast. Social Research.Vol.4, No. 6.

Maghsudi, M. (1991 a). Theory of internal colonialism and unbalanced development in the analysis of ethnic conflicts. Journal of Political- economical Information, 4. No. 149 \& 150.

(1991 b). Ethnic unconformity, some outcomes of political-social harmony. Journal of National Studies. 1(1).

. (1999). Elites, ethnicity \& ethnic violence: A case study of crisis in Azerbaijan of Iran(1945-1946). Journal of Daneshname.

No. $32 \& 33$.

(2001). Ethnicity \& cultural identity. Journal of Iran nameye Pajouhesh, 6: 22 \& 23.

Marger, M. ( ). Ethnic police. In: Encyclopedia of Government and politics. London: Routledge, p. 992.

Martineello, M. (1995). Lethnieitedans les sciences socialescontemplraines, puf, paris

Martiniello, M. (1995). Lethnicite and sciences socials contemporines,puf.paris.

Olson, M. (1918). The logicalness of collective actions, tr. Fransais, paris puf.

Ooman, T. K. (1997). Citizenship, nationality and ethnicity. Cambridge polity press, P. 36.

Ramazanzade, A. (1998). The process of ethnic crisis in Iran. Journal of Strategic Studies. Institute of strategic studies.

Sadroddin, Z. (1998). Iranian ethnic plurality \& national identity. Tehran: Andishe now.

Sadrolashrafi, Z. (1999). Again on ethnic plurality \& Iranian national identity. Journal of Teribun. No. 4.

Sedigh Owraee, Gh. \& Heidari, M. (2009). Study of the political-social divergence in Khorasan. Jahad Daneshgahi of Mashhad reports.

Sills, D. (1960). International encyclopedia of the social sciences, P. 67.

Smith, A. D. (1993). The ethnic sources of nationalism. Survival. No. ,PP. 48-62.

Smith, A. D. (1998). Ethnic resources, nationalism. Journal of strategic studies. Translation office. Forefront No.1

Tabatabayee, S. M. H. (1984). Tafsire Almizan. Translated by: Seyed Mohamad Bagher Musavi Hamedani. Qom: Entesharate Eslami.

Tabriznia, H. (1992). Reasons of unstability of political parties in Iran. Tehran: Nashre beinolmelal.

Tiryakion, E. A. and Rogoewski, R. (1985). New nationalisms of the Developed west. Winchester, Mass: Allenunwin.

Uslaner, M. (1986). One nation, many voices: Interest Groups in foreign policy Makning. In: Interest Group polities, Edities, Edited by A.cigler and B.loomis; Washington,D.G.CQ, PP.236-257.

Weiner, R. (1960). Violence in pre - modern societies. American political science review, Vol. 60.

Yusefi, A. (2004). Kavosh 1, 2, 3. Research articles of Interior Ministry. Vice president of social affairs office.

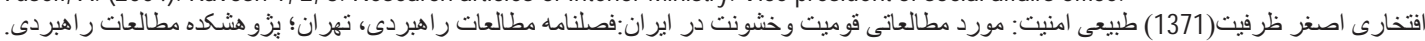

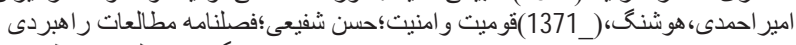

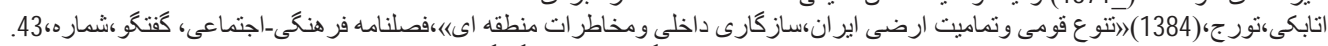

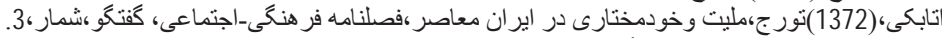

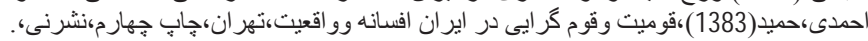

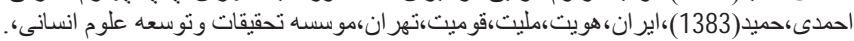

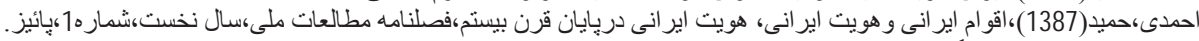

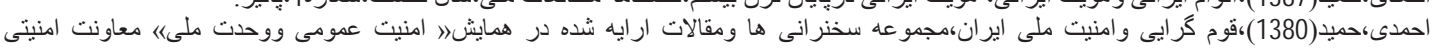

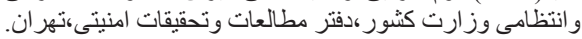

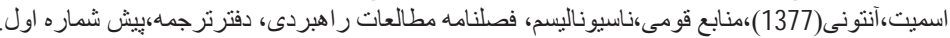

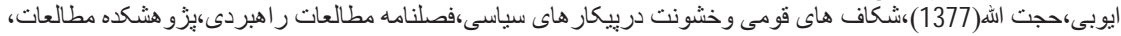

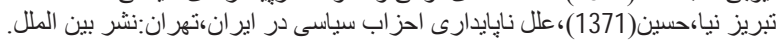




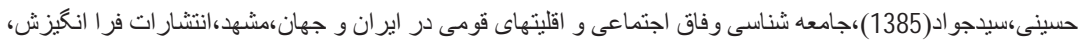

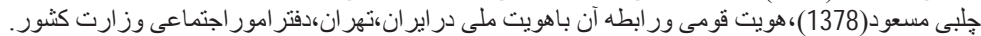

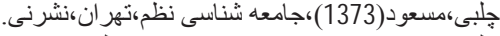

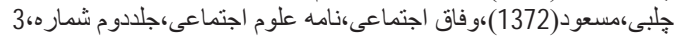

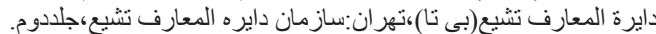

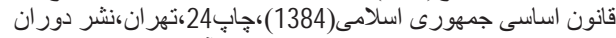

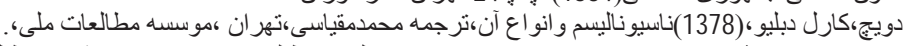

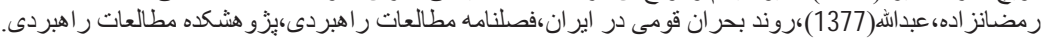

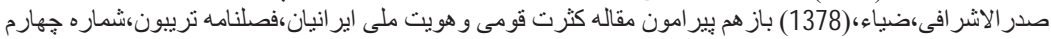

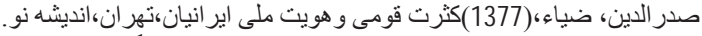

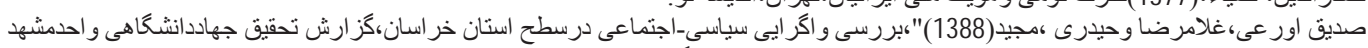

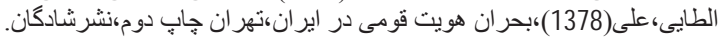

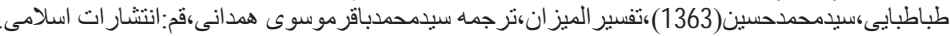

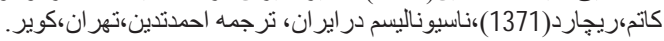

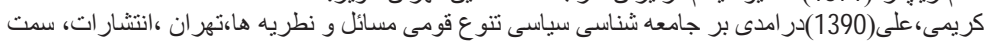

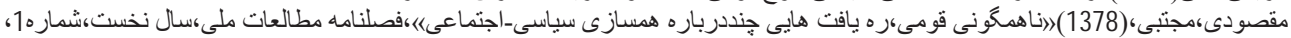

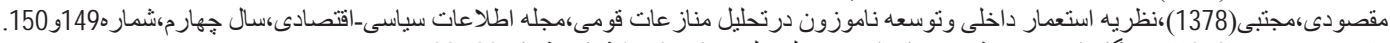

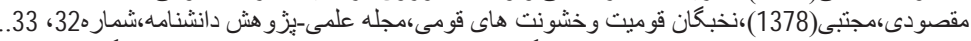

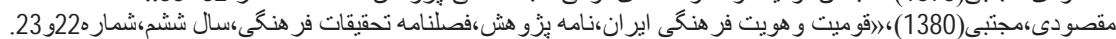

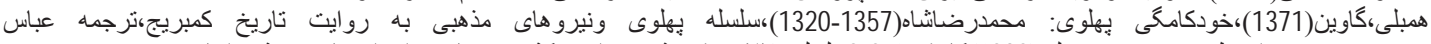

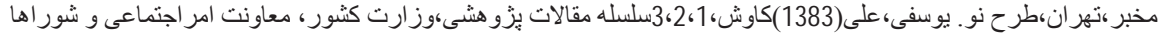

